\title{
MEMORIAL
}

\section{MACKENZIE GORDON, JR.}

(1913-1992)

Mackenzie Gordon, Jr., 78 (Figure 1), was a geologist and paleontologist with the U.S. Geological Survey (USGS) for more than 40 years. Mac, as he was affectionately known, died of cardiac arrest at his home on 30 January 1992 after a very brief illness. He is survived by his wife Barbara Walker Gordon of Washington, D.C.

Born in San Francisco on 4 April 1913 and raised in the Bay area, Mac earned an A.B. in geology from Stanford University in 1934, where he also attended graduate school (1935-1936). There, he studied paleontology and biostratigraphy under Prof. Siemon W. Muller, a dynamic, engaging stratigrapher and field geologist, who introduced Mac to his first love, ammonoids.

Mac had a broad career within the USGS, the scope of his expertise ranging from metals commodities to the geology of the Carboniferous System. Mac fervently believed that solid taxonomic studies are building blocks essential for the establishment and revision of regional and international biostratigraphic frameworks and that meaningful biostratigraphic analysis involves integration of data from all available biotic groups. Furthermore, he maintained that biostratigraphy is not an end in itself but should be utilized as an instrument in solving geologic problems. Throughout his career, Mac prided himself on providing paleontologic and biostratigraphic expertise and support for the USGS's geologic mapping programs. He received considerable international recognition for his contributions to the biostratigraphy and chronostratigraphy of the Carboniferous. He was a voting member of the Carboniferous Subcommission of the International Stratigraphic Commission, served for two decades as the United States Representative on the Permanent Committee for the International Carboniferous Congress, and was the Chairman of the Working Group on the Chesterian and Morrowan Series for the Carboniferous Subcommission. He actively investigated several of the sequences that were being considered for the Mississippian-Pennsylvanian boundary stratotype (the northern Confusion Range in westcentral Utah and the eastern Appalachian sections in southwestern Virginia and southern West Virginia).

His own paleontologic research focused on the study of two major groups of invertebrate fossils-mollusks (mainly cephalopods) and brachiopods. During his career, Mac published more than 100 scientific papers, including several major monographs. Although he retired from the USGS in 1981, he continued his research and publication as an emeritus scientist with the USGS and as a research associate of the Smithsonian Institution (Museum of Natural History) in Washington, D.C. Several major unpublished contributions are currently in review. His more significant stratigraphic and biostratigraphic papers are given in the Selected Bibliography section.

After briefly working for a mining company in the Great Basin after college, Mac embarked on his professional career as a geologist with the USGS in early 1940, shortly before American entry into the Second World War. His work for the USGS prior to and during the War involved mapping of strategic minerals in the Dominican Republic and mineral-resource appraisals of three major metal commodities in the United States - tungsten in California and Arizona, manganese in the Batesville District of Arkansas, and bauxite in central Arkansas. He played a crit-

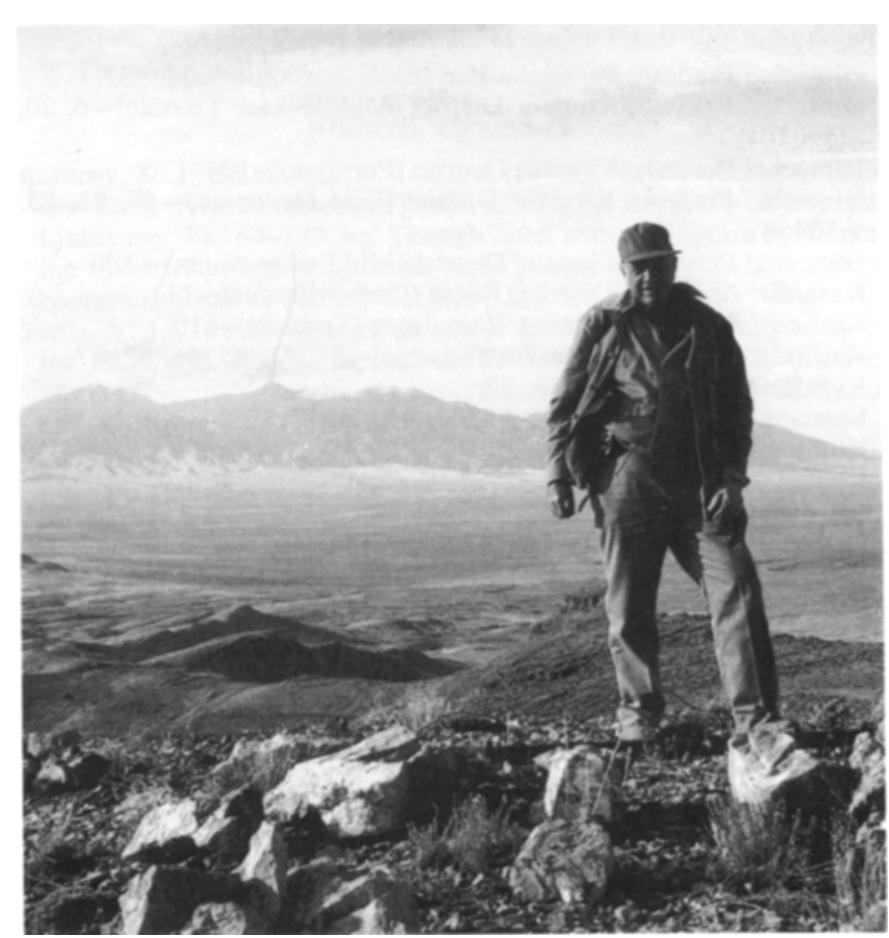

FIGURE 1-Mackenzie Gordon, Jr., at the top of Granite Mountain at the northern end of the Confusion Range, Utah. Looking northwest toward Deep Creek Mountains. Photograph taken by T. W. Henry, 15 October 1983.

ical role for the Government from 1942 to 1945 by leading the Arkansas bauxite project, during which rich and extensive deposits of this strategic material near Little Rock were drilled, blocked out, assessed, and subsequently exploited for the war effort. In 1959, the results of this work were published (coauthors J. I. Tracey, Jr., and M. W. Ellis) as USGS Professional Paper 299, "Geology of the Arkansas Bauxite Region," a monograph that is still widely cited. Mac considered this endeavor the most significant of his career as a public servant.

From 1945 to 1947 , Mac was assigned to the Foreign Geology Branch of the USGS and studied Carboniferous and Permian stratigraphy in southern Brazil. He was in charge of the field office in Rio de Janeiro. In 1950, Mac requested assignment to the Paleontology and Stratigraphy Branch (P\&S) of the USGS where he conducted research for most of the rest of his long career. He was in charge of the Upper Paleozoic Unit of P\&S from 1951 to 1956 and spent 1956-1958 in the USGS's office in Menlo Park, California, where he assisted in establishing the regional research center. Mac returned to Brazil in 1958-1960 and participated in the U.S. Government's international program to establish geology departments in selected Latin American universities. Mac organized and taught, in Portuguese, courses in stratigraphy, paleontology, and sedimentology, established a summer field camp at the Universidade de Rio Grande do Sul in Porto Alegre, and (in 1960) was an advisor at the 
Universidade de Brasil in Rio de Janeiro. For these efforts, he was honored by the Brazilian Geological Society in 1964.

Mac's career was marked by honors and professional responsibilities outside the USGS in addition to those mentioned above. He was a member or a fellow of The Paleontological Society, Society of Economic Paleontologists and Mineralogists, the $\mathrm{Pa}$ laeontological Association, American Malacological Union, the Geological Society of America, California Academy of Sciences, American Association of Petroleum Geologists, the American Geological Institute (past president), and president of the Ninth International Congress on Carboniferous Stratigraphy and Geology (held as part of the USGS Centennial celebration in 1979 in Washington, D.C., and Champaign-Urbana, Illinois) and editor-in-chief of its Proceedings. Other scientific affiliations included the Geological Society of Washington (past councilor and vice president), and the Paleontological Society of Washington (past president). He was a Research Associate of the Smithsonian Institution.

Those of us who knew Mac Gordon were aware that, if there were a piano available, he would quickly target it and begin playing. One of the prominent features of the Gordons' living room in Georgetown was a much-loved and much-used baby grand. For many years, Mac, an accomplished musician, composed music and lyrics for the satirical reviews sponsored by the USGS's Pick and Hammer Clubs in Washington, D.C., and in Menlo Park. He contributed dozens of lyrics for songs in the annual shows during the 1950's and 1960's, culminating with the production for the annual meeting of the Geological Society of America in Washington, D.C., in 1971. For that extravagan$\mathrm{za}$, Mac wrote the lyrics and music of eight songs for the show, called "The Birth of a Notion, or the Weaning of the West," celebrating the founding of the USGS. Mac also performed in these shows, sometimes alternating roles as accompanist and song-and-dance man, as the occasion required. These theatrical talents were developed early on at Stanford, where Mac was a moving force in the yearly student reviews.

Mac was also a recognized expert in ancient Chinese art and history and, beginning in his teens, started to acquire bronze mirrors, an activity that resulted in his amassing one of the world's finest private collections. He and his wife Barbara were also collectors of western contemporary art and were active in local art circles. Mac served on the Board of Directors of the Friends of the Corcoran Art Gallery and was chairman of its Acquisition Committee. The Gordons also were extensively involved with the Washington Society for the Performing Arts. Mac was a long-time member of the Kenwood Country Club and was active in the Christian Science Church, where he held several church offices. During the last decade of his life, Mac became an avid birdwatcher. Asked why, he replied, logically: "All my career as a geologist, I have had my eye to the ground, looking at the rocks, keeping my eye out for mineral traces, and searching for fossils. When you walk across a piece of ground, you have to keep a close watch on the ground not to miss something important. Now, I have retired. And, for the first time in many years, I can look up at the sky. I can see the trees, the clouds, the birds, and the blue sky itself. Birdwatching gives me an excuse to do this. I enjoyed looking at the ground, but now I choose to look at the sky. And, like the earth, it is beautiful!"

We will miss you, Mac!

SELECTED BIBLIOGRAPHY OF MACKENZIE GORDON, JR.

Bouroz, A., R. G. Wagner, Mackenzie Gordon, JR., S. V. Meyen, AND O. L. EINOR. 1977. Predlozheniya po sozdaniytu mezhduna- rodnoi stratigraficheskoi shkaly karbona [Proposals for an international stratigraphic classification of the Carboniferous]. Akad. Nauk SSSR Izvestia, Serie Geologie, 2:5-24. [In Russian; French translation published in Industrie Minerale, 6(10):469-483.]

Closs, DarCy, ANd Mackenzie Gordon, JR. 1966. An upper Paleozoic goniatite radula. Notas e Estudos, Rio Grande do Sul Universidade, Escola Geologia, 1(2):79-81.

CoATs, R. R., AND MACKenzie Gordon, JR. 1972. Tectonic implications of the presence of the Edna Mountain Formation in northern Elko County, Nevada. U.S. Geological Survey Professional Paper 800-C:85-94.

Dutro, J. T., Jr. Mackenzie Gordon, JR., AND J. W. Huddle. 1979. Paleontological zonation of the Mississippian System, p. 83-88. In L. C. Craig and C. W. Connor (coordinators), Paleotectonic Investigations of the Mississippian System in the United States. Part II. Interpretative Summary and Special Features of the Mississippian System. U.S. Geological Survey Professional Paper 1010-S.

Gordon, MACKenzie, JR. 1944. Moorefield formation and Ruddell shale, Batesville district, Arkansas. American Association of Petroleum Geologists Bulletin, 28:1626-1634.

. 1957. Mississippian cephalopods of northern and eastern Alaska. U.S. Geological Survey Professional Paper 283, 61 p.

1960. Some American Midcontinent Carboniferous cephalopods. Journal of Paleontology, 34:134-151.

. 1962. Species of Goniatites in the Caney Shale of Oklahoma. Journal of Paleontology, 36:355-357.

1962 [1963]. Class Cephalopoda, p. 95-96. In M. R. Mudge and E. L. Yochelson, Stratigraphy and Paleontology of the Uppermost Pennsylvanian and Lowermost Permian Rocks in Kansas. U.S. Geological Survey Professional Paper 323.

- 1964. California Carboniferous cephalopods. U.S. Geological Survey Professional Paper 483-A, 27 p.

-. 1964 [1965]. Carboniferous cephalopods of Arkansas. U.S. Geological Survey Professional Paper 460, 96 p.

1966. Permian coleoid cephalopods from the Phosphoria Formation in Idaho and Montana. U.S. Geological Survey Professional Paper 550-B:28-35.

. 1966. Classification of Mississippian coleoid cephalopoda. Journal of Paleontology, 40:449-452.

- 1966. New spinose early Meramec (Upper Mississippian) productoid brachiopods. Journal of Paleontology, 40:573-584.

- 1968. Early Reticuloceras zone fauna from the Hale Formation in northwestern Arkansas. U.S. Geological Survey Professional Paper 613-A, 19 p.

- 1969. Early Pennsylvanian ammonoids from southern Nevada. U.S. Geological Survey Professional Paper 613-C, 13 p.

- 1970. Carboniferous ammonoid zones of the south-central and western United States. Sixième Congrès International de Stratigraphie et Géologie du Carbonifere, Sheffield, Compte Rendu, 2:817-826.

. 1971. Carlinia, a Late Mississippian genus of Productidae from the western United States, p. 257-265. In J. T. Dutro, Jr. (ed.), Paleozoic Perspectives. A Paleontological Tribute to G. Arthur Cooper. Smithsonian Contributions to Paleobiology, no. 3.

. 1971. Biostratigraphy and age of the Carboniferous formations, p. 34-55. In D. A. Brew (ed.), Mississippian Stratigraphy of the Diamond Peak Area, Eureka County, Nevada. U.S. Geological Survey Professional Paper 661.

- 1971. Primitive squid gladii from the Permian of Utah. U.S. Geological Survey Professional Paper 750-C:34-38.

- . 1971. Goniatites americanus n. sp., a late Meramec (Mississippian) index fossil. U.S. Geological Survey Professional Paper 750-C: $39-43$.

. 1974. The Mississippian-Pennsylvanian boundary in the United States. Septième Congrès International de Stratigraphie et Géologie du Carbonifere, Krefield, Compte Rendu, 3:129-141.

- 1976. Brachiopoda of the Amsden Formation (Mississippian and Pennsylvanian) of Wyoming. U.S. Geological Survey Professional Paper 848-D, $86 \mathrm{p}$

- 1982. Biostratigraphy of the Watahomigi Formation, p. 113135. In E. D. McKee (ed.), The Supai Group of the Grand Canyon. U.S. Geological Survey Professional Paper 1173.

- 1986. Late Kinderhookian (Early Mississippian) ammonoids of 
the western United States. Journal of Paleontology, 60(3), Memoir $19,36 \mathrm{p}$.

- AND Helen DunCan. 1961. Early Mississippian faunas in southwestern Elko County, Nevada. U.S. Geological Survey Professional Paper 424-C:233-234.

, AND - 1970. Biostratigraphy and correlation, p. 38-57. In E. W. Tooker and R. J. Roberts, Upper Paleozoic rocks in the Oquirrh Mountains and Bingham Mining District, Utah. U.S. Geological Survey Professional Paper 629-A.

- AND T. W. Henry. 1981. Late Mississippian and Early Pennsylvanian invertebrate faunas, east-central Appalachians-preliminary report, p. 165-171. In K. J. Englund and T. W. Henry (eds.), Mississippian-Pennsylvanian Boundary in the Central Part of the Appalachian Basin, Part I. Southwestern Virginia-Southern West Virginia. Geological Society of America Annual Meeting Guidebook, Field Trip no. 4.

- AND - 1990. Marginovatia, a mid-Carboniferous genus of linoproductid brachiopods. Journal of Paleontology, 64:532-551.

- ASSISTED BY T. W. HENRY. In review. Late Mississippian ammonoids of the Chainman Shale, west-central Utah. U.S. Geological Survey Professional Paper.

- T. W. HenRy, AND B. L. MAMET. 1985. Carboniferous succession and Mississippian-Pennsylvanian boundary, Granite Mountain, Utah, U.S.A. Dixième Congrès International de Stratigraphie et de Géologie du Carbonifere, Madrid, Compte Rendu, 4:441-450.

,-- AND P. K. SuTHERLAND. 1982. Brachiopod zones delimiting the Mississippian-Pennsylvanian boundary in the United States, p. 83-88. International Union of Geological Sciences, Subcommission on Carboniferous Stratigraphy, Symposium Proceedings, A MidCarboniferous Boundary. Leeds, Yorkshire, United Kingdom.

,-- , AND J. D. TREWORGY. 1993. Late Mississippian productoid brachiopods Inflatia, Keokukia, and Adairia, Ozark region of Oklahoma and Arkansas. Journal of Paleontology, 67(3), Memoir 30, 29 p.

- AND B. L. MAMET. 1978. The Mississippian-Pennsylvanian boundary, p. 327-335. In G. V. Cohee, M. F. Glaessner, and H. D. Hedberg (eds.), Contributions to the geologic time scale. American Association of Petroleum Geologists Studies in Geology, no. 6.

, AND C. E. MASON. 1985. Progradation of the Borden Formation in Kentucky, U.S.A., demonstrated by successive Early Mississippian (Osagean) ammonoid faunas. Dixième Congrès International de Stratigraphie et de Géologie du Carbonifere, Madrid, Compte Rendu, 4:191-198.

- and C. W. Merriam. 1961. Late Permian ammonoids in the Inyo Range, California, and their significance. U.S. Geological Survey Professional Paper 424-D:238-239.

- AND John POJETA, JR. 1975. Pelecypoda and Rostroconcha of the Amsden Formation (Mississippian and Pennsylvanian) of Wyoming. U.S. Geological Survey Professional Paper 848-E, 24 p.

-, AND F. G. POOLE. 1967. Mississippian-Pennsylvanian boundary in southwestern Nevada and southeastern California, p. 157-168. In E. B. Eckel (ed.), Nevada Test Site. Geological Society of America, Memoir 110.

- AND C. G. STONE. 1977. Correlations of the Carboniferous rocks of the Ouachita trough with those of the adjacent foreland, p. 70-91.
In Symposium on the Geology of the Ouachita Mountains, Vol. 1, Stratigraphy, Sedimentology, Petrography, Tectonics, and Paleontology. Arkansas Geological Commission.

- AND E. L. Yochelson. 1976. Gastropoda, Cephalopoda, and Trilobita of the Amsden Formation (Mississippian and Pennsylvanian) of Wyoming. U.S. Geological Survey Professional Paper 848$\mathrm{F}, 30 \mathrm{p}$

- AND - 1983. A gastropod fauna from the Cravenoceras hesperium ammonoid zone (Upper Mississippian) in east-central Nevada. Journal of Paleontology, 57:971-991.

— AND - 1987. Late Mississippian gastropods of the Chainman Shale, west-central Utah. U.S. Geological Survey Professional Paper $1868,112 \mathrm{p}$

Henry, T. W., ANd Mackenzie Gordon, JR. 1979. Late Devonian through Early Permian(?) invertebrate faunas in proposed Pennsylvanian stratotype area, p. 97-103. In K. J. Englund et al. (eds.), Proposed Pennsylvanian System Stratotype, Virginia and West Virginia. Ninth International Congress of Carboniferous Stratigraphy and Geology, Field Trip no. 1, American Geological Institute Selected Guidebook Series no. 1.

- AND - 1985. Chesterian davidsoniacean and orthotetacean brachiopods, Ozark region of Arkansas and Oklahoma. Journal of Paleontology, 59:32-59.

- AND - 1992. Middle and upper Chesterian brachiopod biostratigraphy, eastern Appalachians, Virginia and West Virginia. Oklahoma Geological Survey Circular 94:1-21.

- AND - In review. Brachiopod faunas and biostratigraphy of the Pennington Group (Middle and Late Chesterian) of the eastern Appalachians. U.S. Geological Survey Professional Paper.

,-- S. P. SChWEINFURTH, AND W. H. GILleSPIE. 1985. Significance of the goniatite Bilinguites eliasi and associated biotas, Parkwood Formation and Bangor Limestone, northwestern Alabama. Journal of Paleontology, 59:1138-1145.

PoOle, F. G., P. P. Orkild, ANd Mackenzie Gordon, Jr. 1965. Age of the Eleana Formation (Devonian and Mississippian) in the Nevada Test Site. U.S. Geological Survey Bulletin 1224-A:51-53.

Sando, W. J., MACKenzie Gordon, JR., AND J. T. DUTRo, JR. 1975 [1976]. Stratigraphy and geologic history of the Amsden Formation (Mississippian and Pennsylvanian) of Wyoming. U.S. Geological Survey Professional Paper 848-A, 83 p.

SAUNDERS, W. B., W. L. MANGer, AND MACKenzie Gordon, JR. 1977. Upper Mississippian and Lower and Middle Pennsylvanian ammonoid biostratigraphy of northern Arkansas. Oklahoma Geological Survey Guidebook 18:117-137.

Webster, G. D., Paul Brenckie, Mackenzie Gordon, Jr., H. R. Lane, R. L. Langenheim, JR., and G. A. Sanderson. 1984. The Mississippian-Pennsylvanian boundary in the eastern Great Basin. Neuvième Congrès International de Stratigraphie et Géologie du Carbonifere, Champaign-Urbana and Washington, D.C., Compte Rendu, $2: 406-418$.

Thomas W. Henry' and J. Thomas Dutro, Jr. ${ }^{2}$ U.S. Geological Survey

'Denver, CO 80225 and

${ }^{2}$ Washington, DC 20560 